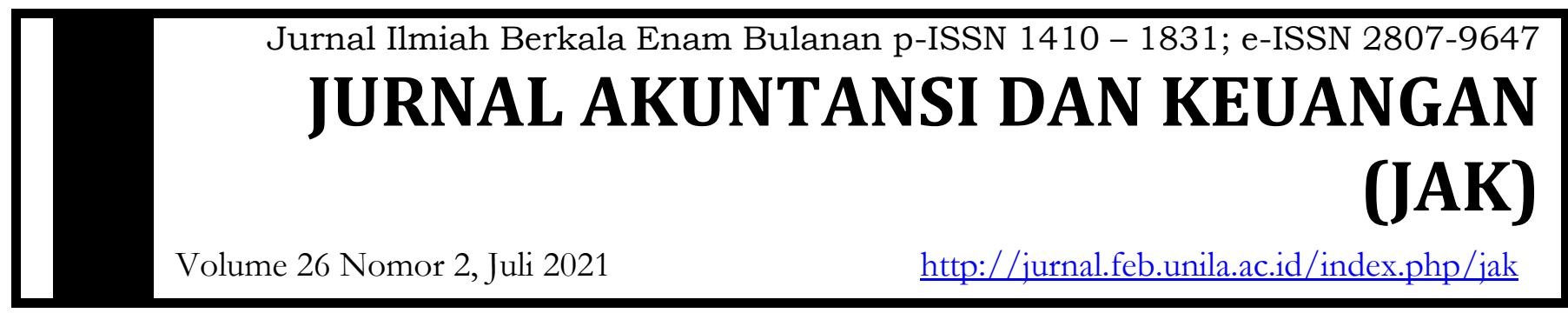

\title{
KUALITAS INFORMASI AKUNTANSI SEKTOR INDUSTRI SEBELUM DAN SELAMA PANDEMI COVID-19: STUDI NEGARA-NEGARA ASEAN
}

\author{
Slamet Sugiri' ${ }^{1}$, Retno Yuni Nur Susilowati ${ }^{2}$ \\ ${ }^{1}$ Fakultas Ekonomika dan Bisnis, Universitas Gadjah Mada \\ ${ }^{2}$ Fakultas Ekonomi dan Bisnis, Universitas Lampung
}

\section{Informasi Naskah}

Update Naskah:

Dikumpulkan: 3 Juni 2021

Diterima: 17 Juli 2021

Terbit/Dicetak: 30 Juli 2021

\section{Keywords:}

Covid-19, ASEAN, accounting information quality, accruals quality, value relevance

\section{$\underline{\text { Abstract }}$}

The purpose of this paper is to examine the effect of the Covid19 pandemic on the quality of accounting information in terms of accrual quality and value relevance. This study uses a sample of companies listed on stock exchanges in five ASEAN countries, Indonesia, Malaysia, the Philippines, Singapore, and Thailand, for the period 2009-2020. OLS pooled regression model was estimated with panel data. The results showed that the COVID19 pandemic impacted earnings quality, but not on value relevance of accounting information quality. Enforcement of accounting and auditing standards can reduce the impact of the COVID-19 pandemic in improving earnings quality. However, investor protection is not adequate to improve the quality of accounting information during the COVID-19 pandemic. 


\section{A. PENDAHULUAN}

Pandemi Covid-19 telah memberikan dampak yang signifikan terhadap seluruh aktivitas kehidupan dan bisnis. Pandemi ini mengakibatkan berkurangnya aktivitas perdagangan internasional untuk menekan penyebaran virus. Ini menyebabkan dampak yang luar biasa pada aktivitas ekonomi dan pasar keuangan di seluruh dunia. Indeks pasar saham AS S\&P 500 anjlok hampir 34 persen dari 20 Februari hingga 23 Maret 2020 (Bloomberg, n.d.). Hal yang sama dilaporkan oleh nilai indeks Kroasia CROBEX (Bursa Efek Zagreb, n. d.). Penurunan ini mengikuti penurunan sebelumnya $11 \%$ dari indeks pasar saham China CSI 300 dari 23 Januari hingga 3 Februari 2020 (China Securities Index, n.d.).

Dampak pandemi COVID-19 pada pasar keuangan dan kinerja keuangan perusahaan beragam (Palma-Ruiz et al., 2020). Belum jelas berapa lama krisis akibat virus Covid-19 ini akan berlangsung, sehingga belum bisa memperkirakan dampak kerugiannya. Tekanan yang dihadapi manajemen memunculkan potensi manipulasi informasi akuntansi untuk memenuhi target dan ekspektasi pasar. Manajemen mungkin mencoba menggunakan diskresi akuntansi untuk menyesuaikan laporan keuangan dengan ekspektasi pesimistis tentang masa depan. Penelitian sebelumnya terkait dampak krisis belum konklusif. Beberapa penelitian menunjukkan peningkatan manajemen laba selama krisis keuangan dan ekonomi (Silva et al., 2014; Flores et al., 2016), sementara yang lain mendokumentasikan penurunan manajemen laba selama krisis. Kinerja perusahaan yang buruk diduga mengurangi niat manajemen laba (Chintrakarn et al., 2018) atau kebutuhan untuk menarik investor (Cimini, 2015).

Investor dan pemangku kepentingan lainnya harus menentukan prospek keuangan perusahaan di masa depan, yaitu melalui kualitas informasi akuntansi. Tujuan penelitian ini adalah untuk menginvestigasi pengaruh pandemi COVID-19 terhadap kualitas informasi akuntansi. Pandemi COVID-19 diduga berdampak pada penurunan kualitas informasi akuntansi. Penelitian sebelumnya menyatakan bahwa krisis mengurangi kualitas akrual (misalnya, Persakis \& Iatridis, 2015; Kousenidis et al., 2013; Chen et al., 2018) dan relevansi nilai informasi akuntansi (Graham et al., 2000; Choi et al., 2011; Adwan et al., 2020).

Penelitian ini berkontribusi pada literatur sebagai berikut. Pertama, penelitian ini merupakan salah satu studi pertama yang menyelidiki kualitas informasi akuntansi dalam praktik negara-negara ASEAN di tengah pandemi yang sedang berlangsung. Negara-negara ASEAN adalah negara-negara yang beberapa di antaranya merupakan negara berkembang. Secara finansial, negara-negara tersebut sangat mungkin terdampak oleh Covid-19. Kedua, penelitian ini memperluas Palma-Ruiz (2020) dengan menguji kualitas informasi akuntansi baik dari perspektif akuntansi maupun pasar selama krisis pandemi. Terakhir, penelitian ini membantu otoritas negara ASEAN dan investor untuk lebih memahami bagaimana Covid19 memengaruhi praktik akuntansi dan kualitas informasi akuntansi. Implikasi praktisnya adalah pada kualitas informasi akuntansi perusahaan publik, yang dapat menurun karena motivasi untuk menampilkan laporan keuangan yang terlihat berbeda dari apa adanya. Secara teoretis, penelitian ini akan menambah literatur tentang kualitas informasi akuntansi, khususnya laporan keuangan yang diterbitkan selama pandemi COVID-19.

\section{B. LANDASAN TEORI DAN PENGEMBANGAN HIPOTESIS}

\section{Kualitas Informasi Akuntansi dan Pandemi Covid-19}

Teori pemangku kepentingan menekankan interkoneksi antara bisnis dan semua pihak yang berkepentingan di dalamnya: pelanggan, karyawan, pemasok, investor, dan masyarakat. Ini menunjukkan bahwa perusahaan harus berusaha untuk memaksimalkan nilai bagi para pemangku kepentingannya (Freeman, 1984). Menurut Freeman (1984), perusahaan menempatkan semua pemangku kepentingan pada risiko karena aktivitas perusahaan, yang melegitimasi klaim semua pemangku kepentingan terhadap proses pengambilan keputusan perusahaan. Teori fraud triangle (Cressey, 1950; Schuchter \& Levi, 2016), menjelaskan motivasi bagi perusahaan untuk menyesuaikan hasil keuangannya dengan harapan masa depan. Selama krisis keuangan, investor dan pelaku pasar lainnya lebih memperhatikan keuntungan yang 
cenderung tidak stabil dan menunjukkan pola yang menurun.

Peran informasi akuntansi untuk penilaian perusahaan ketika kesehatan keuangan perusahaan memburuk adalah subjek dari beberapa studi dalam literatur akuntansi (misalnya Barth et al., 1998; DavisFriday et al., 2006). Penelitian sebelumnya menyebutkan bahwa COVID-19 berdampak besar pada aktivitas bisnis, misalnya penurunan kinerja keuangan (Rababah et al., 2020; Shen et al., 2020). DeFond \& Park (1997) menemukan bahwa ketika estimasi kinerja masa depan berada di bawah standar capaian finansial tahun sebelumnya, manajemen cenderung mentransfer laba ke periode mendatang dan sebaliknya. Sejak krisis COVID-19 terjadi, perusahaan diduga memiliki motivasi untuk mengalihkan sebagian keuntungannya dari tahun sebelumnya ke periode mendatang.

Literatur sebelumnya telah menguji penilaian pasar dari informasi akuntansi ketika kondisi keuangan perusahaan memburuk (misalnya, Davis-Friday et al., 2006; Burgstahler \& Dichev, 1997; Barth et al., 1998). Kualitas informasi akuntansi berkaitan dengan kegunaan informasi akuntansi bagi pengguna laporan keuangan. Kualitas informasi akuntansi merupakan suatu tingkatan, yang dalam hal ini pelaporan keuangan dapat mencerminkan kondisi ekonomi perusahaan yang sebenarnya. Karena perubahan nilai pasar tidak dapat diprediksi dan item laporan keuangan diperbarui setiap periode, laba menjadi lebih tidak stabil dan kurang persisten. Laba yang kurang persisten kurang dapat diprediksi dan kurang berguna untuk penilaian ekuitas (Bhattacharya et al., 2003; Dichev \& Tang, 2009).

Adwan et al. (2020) menemukan bukti adanya penurunan secara signifikan relevansi nilai laba bersih pada saat krisis keuangan. Studi sebelumnya berfokus pada dampak krisis keuangan pada relevansi nilai informasi akuntansi (yaitu, nilai buku ekuitas dan laba bersih). Sebagai contoh, Graham et al., (2000) menemukan bahwa setelah krisis keuangan di Thailand, relevansi nilai dari nilai buku ekuitas perusahaan meningkat, sedangkan relevansi nilai laba bersih menurun. Sementara itu, Davis-Friday et al., (2006) mengungkapkan variasi relevansi nilai dari nilai buku ekuitas dan laba bersih setelah krisis keuangan Asia.

Menurut Chintrakarn et al. (2018), manajer dapat memanipulasi laba yang dilaporkan secara lebih agresif selama krisis keuangan. Skenario pandemi saat ini juga menentukan penerapan manajemen laba. Peningkatan manajemen laba akan menurunkan kualitas informasi akuntansi. COVID-19 berdampak signifikan terhadap aktivitas ekonomi emiten di negara-negara ASEAN. Oleh karena itu, hipotesis pertama adalah sebagai berikut:

\section{H1: Pandemi COVID-19 mempengaruhi kualitas informasi perusahaan yang terdaftar di negara- negara ASEAN.}

\section{Dampak Faktor Institusional Negara pada Kualitas Informasi Akuntansi}

Literatur akuntansi dan keuangan membuktikan bahwa infrastruktur kelembagaan yang kuat dari suatu negara sangat penting dalam menentukan perilaku oportunistik manajerial dan kualitas informasi akuntansi (misalnya, Leuz et al., 2003; Fernandes \& Ferreira, 2008; Kim \& Shi, 2011). Penelitian ini menduga bahwa perlindungan investor dan penegakan standar akuntansi sangat penting untuk kredibilitas informasi akuntansi yang dilaporkan selama krisis. Namun sebaliknya, lembaga hukum tingkat negara diduga hanya memiliki peran pelengkap dalam nilai informasi akuntansi (misalnya, Ball et al., 2003; Choi \& Wong, 2007). Konsisten dengan argumen ini, Hung, (2000) melaporkan bahwa relevansi nilai akrual lebih rendah di negara-negara dengan institusi hukum yang lemah dibandingkan dengan institusi yang kuat. Oleh karena itu, penelitian ini mengajukan hipotesis alternatif sebagai berikut:

H2: Faktor institusional negara (yaitu, perlindungan investor dan penegakan standar akuntansi) berdampak pada hubungan antara pandemi COVID-19 dan kualitas informasi akuntansi.

\section{METODE PENELITIAN}

\section{Data dan Sampel}

Data pada penelitian ini adalah data sekunder berupa laporan keuangan perusahaan nonkeuangan yang terdaftar di lima negara ASEAN (yaitu, Indonesia, Malaysia, Filipina, Singapura, dan Thailand). 
Penelitian ini berfokus pada negara-negara ASEAN karena empat dari lima negara ASEAN merupakan negara berkembang yang memiliki kemungkinan besar terdampak pandemi COVID-19. Sumber data diperoleh dari basis data OSIRIS untuk tahun 2009-2020.

\section{Variabel Penelitian}

\section{Ukuran kualitas informasi akuntansi}

Pada penelitian ini, kualitas informasi akuntansi diukur dengan ukuran berbasis akuntansi dan berbasis pasar. Kualitas informasi akuntansi berbasis pasar diukur dengan kualitas laba dengan argumentasi bahwa laba merupakan ukuran dasar yang digunakan oleh investor (Francis et al., 2006). Kualitas laba diukur dengan nilai absolut dari estimasi residual dari model Dechow-Dichev modifikasian (Dechow \& Dichev, 2002). Choi \& Pae (2011) menyatakan bahwa kualitas akrual mencerminkan perilaku oportunistik manajer, yaitu berkaitan dengan laba yang dilaporkan dan reaksi mereka terhadap berita ekonomi yang tidak menguntungkan. Penelitian ini mengikuti McNichols (2002) dan memperkirakan model crosssectional berikut untuk setiap tahun industri (didefinisikan sebagai klasifikasi industri 48 Fama-Francis) sebagai berikut:

$$
A C C_{i t}=\beta 0+\beta_{1} C F O_{i t-1}+\beta_{2} C F O_{i t}+\beta_{3} C F O_{i t+1}+\beta_{4} \Delta R E V_{i t}+\beta_{5} P P E_{i t}+\epsilon_{i t}
$$

ACC didefinisikan sebagai laba sebelum pos luar biasa dan operasi dihentikan dikurangi arus kas operasi (CFO), yang diambil langsung dari laporan arus kas (Hribar \& Collins 2002). REV adalah perubahan penjualan dari tahun sebelumnya, dan PPE (properti, pabrik, peralatan) adalah nilai bruto properti, pabrik, dan peralatan. Properti, pabrik, dan peralatan (PPE) menjelaskan akrual tidak lancar, yang sebagian besar merupakan penyusutan. Kualitas laba diestimasi sebagai residual dari model (1) di semua perusahaan sampel yang diurutkan berdasarkan sektor industri dan tahun. Studi ini mengadopsi pendekatan cross-sectional dari model Dechow-Dichev yang dimodifikasi daripada pendekatan deret waktu spesifik perusahaan. Subramanyam (1996) menunjukkan bahwa model cross-sectional memberikan estimasi parameter yang lebih akurat daripada time-series karena jumlah derajat kebebasan yang lebih besar. Angka residual yang lebih rendah menunjukkan kualitas laba yang lebih tinggi.

Berikutnya, penelitian ini mengikuti Persakis \& Iatridis (2017) dengan menggunakan model relevansi nilai yang diestimasi oleh Ohlson (1995). Ohlson (1995) menggunakan kekuatan penjelas $\left(\mathrm{R}^{2}{ }_{\mathrm{i}, \mathrm{t}}\right)$ dari model regresi berikut:

$$
P_{i t}=\beta 0+\beta_{1} E_{i t}+\beta_{2} B V_{i t}+\epsilon_{i t}
$$

dalam hal ini, $\mathrm{P}_{\text {it }}$ adalah harga saham; Eit adalah harga per saham; $\mathrm{BV}_{\text {it }}$ adalah nilai buku per saham; dan $\varepsilon$ adalah error term. Nilai koefisien $\mathrm{R}^{2}$ yang diperoleh dari regresi model Ohlson (1995) menunjukkan relevansi nilai. Semakin tinggi nilai $\mathrm{R}^{2}$, semakin tinggi relevansi nilai.

\section{Ukuran institusional negara}

\section{Perlindungan investor}

Studi ini menggunakan skor perlindungan investor yang dilaporkan oleh World Economic Forum (The Global Competitiveness Report) 2019. Studi lain menggunakan ukuran berbeda untuk mengukur perlindungan investor, misalnya indeks perlindungan investor oleh La Porta et al., (1998).

\section{Penegakan standar akuntansi dan audit}

Penelitian ini mengikuti Wijayana \& Gray (2018), yang menggunakan pengukuran standar akuntansi dan penegakan audit yang direkomendasikan oleh Brown et al. (2014). Penegakan standar akuntansi dan indeks audit menangkap perbedaan negara dalam lingkungan di mana dewan standar akuntansi beroperasi dan di mana auditor melakukan peran mereka terkait kepatuhan terhadap standar akuntansi (Brown et al., 2014). Indeks gabungan penegakan standar akuntansi dan audit memiliki skor 
maksimum 56 (Brown et al., 2014). Langkah-langkah penegakan akuntansi dan audit yang dikembangkan oleh Brown et al., (2014) secara langsung menangkap kekuatan penegakan pelaporan keuangan dan kualitas audit.

\section{Pengujian Hipotesis}

Penelitian ini menguji H1 dan H2 menggunakan Ordinary Least Square, yang diestimasi menggunakan model berikut:

$$
I Q_{i, t}=\alpha 0+\beta_{1} \text { COVID-19 }+\beta_{2} I N V E S T O R_{i, t}+\beta_{3} \text { ENFORCEMENT } T_{i, t}+\sum \text { CONTROLS }+\epsilon_{i, t}
$$

dalam hal ini,

IQ: kualitas informasi akuntansi (diukur dengan kualitas akrual dan relevansi nilai)

COVID-19: variabel dummy yang ditentukan 0 sebelum pandemi dan 1 selama pandemi

INVESTOR: perlindungan investor (diukur dengan skor perlindungan investor yang dilaporkan dalam Global

Competitiveness Report 2019 yang disediakan oleh World Economic Forum)

PENEGAKAN: standar akuntansi dan penegakan audit (indeks yang dikembangkan oleh Brown et al. 2014)

KONTROL: variabel kontrol yang digunakan dalam penelitian ini meliputi tingkat kelembagaan (sistem hukum dan perkembangan pasar modal) dan tingkat perusahaan (ukuran perusahaan, leverage, dan pertumbuhan).

$\varepsilon:$ istilah error term

Karena data penelitian ini memiliki masalah heteroskedastisitas, penelitian ini melakukan beberapa langkah untuk mengatasi hal tersebut. Penelitian ini melakukan prosedur winsorizing pada 1-99\% dan mengubah variabel observasian menjadi logaritma natural, tetapi tidak berhasil menghilangkan masalah tersebut. Akhirnya, penelitian ini menambahkan perintah 'robust' ke dalam regresi STATA.

Penelitian ini melakukan analisis tambahan untuk menguji perbedaan kualitas akrual dan relevansi nilai sebelum dan selama pandemi COVID-19. Pengujian dilakukan dengan uji-t untuk sampel berpasangan. Data yang digunakan adalah tahun 2019 dan 2020. Analisis kekokohan (robustness test) dilakukan dengan menggunakan ukuran kualitas laba yang lain. Penelitian ini melakukan analisis kekokohan dengan menggunakan estimasi manajemen laba menggunakan model regresi Dechow \& Dichev (2002) untuk data 2009-2020.

\section{ANALISIS DAN PEMBAHASAN \\ Statistik Deskriptif}

Sampel penelitian terdiri atas perusahaan yang terdaftar di lima negara ASEAN, Indonesia, Malaysia, Filipina, Singapura, dan Thailand. Untuk mengukur kualitas laba dan relevansi nilai informasi akuntansi, penelitian ini menggunakan data keuangan yang disediakan oleh OSIRIS pada tahun 2009-2020.

Penelitian ini mengukur kualitas laba menggunakan model residual McNichols (McNichols, 2002), yang diestimasi dari regresi data gabungan 2009-2020 per industri per negara. Relevansi nilai informasi akuntansi diukur dengan koefisien determinasi $\left(\mathrm{R}^{2}\right)$ dari model regresi Ohlson (Ohlson, 1995).

Tabel 1 menunjukkan prosedur pemilihan sampel, sedangkan Tabel 2 menyajikan statistik deskriptif sampel.

Table 1. Sample selection.

\begin{tabular}{lccc}
\hline Country & $\begin{array}{c}\text { Publicly listed } \\
\text { companies }\end{array}$ & Financial sector & Final sample \\
\hline Indonesia & 723 & $(239)$ & 484 \\
Malaysia & 948 & $(85)$ & 863 \\
Philippines & 266 & $(41)$ & 225 \\
Singapore & 628 & $(41)$ & 587 \\
Thailand & 768 & $(113)$ & 655 \\
\hline
\end{tabular}

(Sumber: OSIRIS, 2021)

Tabel 2 menunjukkan bahwa rata-rata (mean) kualitas laba (AQ) adalah 43895.78, sedangkan relevansi nilai 72393.93. Rata-rata negara-negara ASEAN memiliki tingkat perlindungan investor sebesar 72.47932. Penegakan standar akuntansi dan audit memiliki mean sebesar 4.521515. 
Table 2. Descriptive Statistics.

\begin{tabular}{cccccc}
\hline Variable & Obs. & Mean & Std. Dev. & Min & Max \\
\hline AQ & 4,641 & 43895.78 & 235749.7 & -3932009 & 9045943 \\
EM & 4,344 & 72393.93 & 275167.1 & -3932009 & 9045943 \\
VR & 4,925 & -.0056171 & .3062866 & -11.4655 & 4.480403 \\
LNTA & 4,029 & 11.87083 & 1.811285 & 2.935207 & 18.25464 \\
REV & 4,847 & -24763.96 & 447170 & $-1.98 \mathrm{e}+07$ & 7949669 \\
PPE & 4,724 & 537641.3 & 2807870 & 0 & $9.24 \mathrm{e}+07$ \\
GCI & 5,628 & 72.47932 & 7.559493 & 61.9 & 84.8 \\
ENF & 5,628 & 13.43461 & 4.521515 & 6 & 19 \\
MARKET & 5,628 & .7133876 & .203476 & .2868648 & .8362726 \\
DEVELOP & 5,628 & .5152807 & .4998109 & 0 & 1 \\
\hline
\end{tabular}

(Sumber: STATA, 2021)

Penelitian ini menggunakan metode ordinary least square untuk menguji hipotesis. Hasil penelitian menunjukkan bahwa secara statistis, H1 didukung untuk kualitas akrual ( $p$-value $=0.000$ ), tetapi tidak didukung untuk relevansi nilai $(p$-value $=0.584)$.

Tabel 3. Pengujian H1

\begin{tabular}{lcc}
\hline \multicolumn{1}{c}{ VARIABLE } & AQ & VR \\
\hline COVID & $48577.15^{* *}$ & -.00637664 \\
GCI & $14875.426 * * *$ & .00155289 \\
ENF & $16740.293^{* * *}$ & .00213745 \\
MARKET & $-314379.7 * * *$ & -.04666142 \\
DEVELOP & $-210330.82^{* * *}$ & -.02950546 \\
LNTA & $16299.459 * * *$ & -.00307354 \\
REV & .03640063 & $5.926 \mathrm{e}-08$ \\
PPE & $.03517205^{*}$ & $1.448 \mathrm{e}-09$ \\
cons & $-1158153.8^{* * *}$ & -.05732982 \\
\hline
\end{tabular}

Sig. $* \mathrm{p}<0.05 ; * * \mathrm{p}<0.01 ; \overline{* * * \mathrm{p}<0.001}$

(Sumber: STATA, 2021)

Hasil pengujian $\mathrm{H} 2$ menunjukkan bahwa kedua faktor kelembagaan (perlindungan investor dan penegakan standar akuntansi) berdampak pada kualitas akrual ( $p$-value $=0,000)$ dan relevansi nilai $(p$-value $=0,001)$. Namun, hasil yang berbeda membuktikan bahwa faktor institusional (perlindungan investor dan penegakan standar akuntansi) tidak berpengaruh signifikan terhadap relevansi nilai informasi akuntansi $(p$-value $=0,767$ dan $p$-value $=0,762)$.

Tabel 4. Pengujian H2

\begin{tabular}{lcc}
\hline \multicolumn{1}{c}{ VARIABLE } & AQ & VR \\
\hline COVIDGCI & $1459.7035^{*}$ & .00001673 \\
COVIDENF & -4345.909 & -.00066541 \\
MARKET & -20847.316 & -.01018385 \\
DEVELOP & 11481.611 & -.00440344 \\
LNTA & $17066.37 * * *$ & -.00293903 \\
REV & .0361818 & $5.924 \mathrm{e}-08$ \\
PPE & $.03506324 *$ & $1.434 \mathrm{e}-09$ \\
cons & $-188211.85^{* * *}$ & .04371329 \\
\hline
\end{tabular}

Sig. $* \mathrm{p}<0.05 ; * \mathrm{p}<0 . \overline{01 ; * * * \mathrm{p}<0.001}$

(Sumber: STATA, 2021)

Penelitian ini mengontrol faktor perusahaan (yaitu, ukuran perusahaan, leverage, dan pertumbuhan) dan negara (yaitu, perkembangan pasar modal dan kategori berkembang/berkembang). Penelitian ini melakukan uji-t untuk menguji perbedaan kualitas informasi akuntansi sebelum dan selama pandemi COVID-19. Hasil (tidak ditabulasi) menunjukkan adanya perbedaan kualitas akuntansi sebelum dan selama pandemi COVID-19 ( -value=0,000). Uji relevansi nilai menunjukkan tidak ada perbedaan sebelum dan selama pandemi COVID-19 ( $p$-value $=0.8822)$. 


\section{E. SIMPULAN DAN SARAN}

Hasil penelitian menunjukkan bahwa pandemi COVID-19 berdampak pada kualitas akrual sebagai ukuran kualitas informasi akuntansi, tetapi tidak pada relevansi nilai. Penegakan standar akuntansi dan auditing dapat mengurangi dampak pandemi COVID-19 dalam meningkatkan kualitas akrual, tetapi tidak untuk relevansi nilai. Namun secara keseluruhan, perlindungan investor secara signifikan dapat meningkatkan kualitas akrual, tetapi belum memadai untuk meningkatkan relevansi nilai dari informasi akuntansi di masa pandemi COVID-19. Implikasinya adalah memperluas penegakan standar akuntansi untuk mengurangi dampak krisis pada relevansi nilai.

\section{REFERENSI}

Adwan, S., Alhaj-Ismail, A., \& Girardone, C. (2020). Fair value accounting and value relevance of equity book value and net income for European financial firms during the crisis. Journal of International Accounting, Auditing and Taxation, 39, 100320. https://doi.org/10.1016/j.intaccaudtax.2020.100320

Ali, S. H., Foreman, J., Capasso, A., Jones, A. M., Tozan, Y., \& DiClemente, R. J. (2020). Social media as a recruitment platform for a nationwide online survey of COVID-19 knowledge, beliefs, and practices in the United States: methodology and feasibility analysis. BMC Medical Research Methodology, 20, 1-11.

Ball, R., Robin, A., \& Wu, J. S. (2003). Incentives versus standards: Properties of accounting income in four East Asian countries. Journal of Accounting and Economics. https://doi.org/10.1016/j.jacceco.2003.10.003

Barth, M. E., Beaver, W. H., \& Landsman, W. R. (1998). Relative valuation roles of equity book value and net income as a function of financial health. Journal of Accounting and Economics, 25(1), 1-34.

Bhattacharya, N., Black, E. L., Christensen, T. E., \& Larson, C. R. (2003). Assessing the relative informativeness and permanence of pro forma earnings and GAAP operating earnings. Journal of Accounting and Economics, 36(1-3), 285-319.

Brown, P., Preiato, J., \& Tarca, A. (2014). Measuring Country Differences in Enforcement of Accounting Standards: An Audit and Enforcement Proxy. Journal of Business Finance and Accounting, 41(1-2), 1-52. https://doi.org/10.1111/jbfa.12066

Burgstahler, D., \& Dichev, I. (1997). Earnings management to avoid earnings decreases and losses. Journal of Accounting and Economics, 24(1), 99-126.

Chen, L., Krishnan, G. V., \& Yu, W. (2018). The relation between audit fee cuts during the global financial crisis and earnings quality and audit quality. Advances in Accounting, 43(July), 14-31. https://doi.org/10.1016/j.adiac.2018.07.007

Chintrakarn, P., Jiraporn, P., \& Kim, Y. S. (2018). Did firms manage earnings more aggressively during the financial crisis? International Review of Finance, 18(3), 477-494.

Choi, J.-H., Kim, J.-B., \& Lee, J. J. (2011). Value relevance of discretionary accruals in the Asian financial crisis of 1997--1998. Journal of Accounting and Public Policy, 30(2), 166-187.

Choi, J.-H., \& Wong, T. J. (2007). Auditors' governance functions and legal environments: An international investigation. Contemporary Accounting Research, 24(1), 13-46.

Choi, T. H., \& Pae, J. (2011). Business Ethics and Financial Reporting Quality: Evidence from Korea. Journal of Business Ethics, 103(3), 403-427. https://doi.org/10.1007/s10551-011-0871-4

Cimini, R. (2015). How has the financial crisis affected earnings management? A European study. Applied Economics, 47(3), 302-317.

Cressey, D. R. (1950). The criminal violation of financial trust. American Sociological Review, 15(6), 738-743.

Davis-Friday, P. Y., Eng, L. L., \& Liu, C.-S. (2006). The effects of the Asian crisis, corporate governance and accounting system on the valuation of book value and earnings. The International Journal of Accounting, 41(1), 22-40.

Dechow, P. M., \& Dichev, I. D. (2002). The quality of accruals and earnings: The role of accrual estimation errors. Accounting Review, 77(SUPPL.), 35-59. https://doi.org/10.2308/accr.2002.77.s-1.61

DeFond, M. L., \& Park, C. W. (1997). Smoothing income in anticipation of future earnings. Journal of Accounting and Economics, 23(2), 115-139.

Dichev, I. D., \& Tang, V. W. (2009). Earnings volatility and earnings predictability. Journal of Accounting and Economics, 47(1-2), 160-181.

Fernandes, N., \& Ferreira, M. A. (2008). Does international cross-listing improve the information environment. Journal of Financial Economics, 88(2), 216-244.

Flores, E., Weffort, E. F. J., da Silva, A. F., \& Carvalho, L. N. G. (2016). Earnings management and macroeconomic crises: Evidences from Brazil and USA capital markets. Journal of Accounting in Emerging Economies.

Francis, J, Olsson, P., \& Schipper, K. (2006). Earnings quality. Foundation and Trends in Accounting 1 (4): 259-340. 
Francis, Jennifer, LaFond, R., Olsson, P. M., \& Schipper, K. (2004). Costs of Equity and Earnings Attributes. Accounting

Review,

$79(4)$

$967-1010$

http://search.ebscohost.com/login.aspx?direct=true \&db=buh\&AN=14897242\&site=ehost-live

Graham, R., King, R., \& Bailes, J. (2000). The value relevance of accounting information during a financial crisis: Thailand and the 1997 decline in the value of the baht. Journal of International Financial Management and Accounting, 11(2), 84-107. https://doi.org/10.1111/1467-646X.00057

Haroon, O., \& Rizvi, S. A. R. (2020). COVID-19: Media coverage and financial markets behavior-A sectoral inquiry. Journal of Behavioral and Experimental Finance, 27, 100343.

Hribar, P., \& Collins, D. W. (2002). Errors in estimating accruals: Implications for empirical research. Journal of Accounting Research, 40(1), 105-134.

Hung, M. (2000). Accounting standards and value relevance of financial statements: An international analysis. Journal of Accounting and Economics, 30(3), 401-420.

Kim, J. W., \& Shi, Y. (2011). Voluntary disclosure and the cost of equity capital: Evidence from management earnings forecasts. Journal of Accounting and Public Policy, 30(4), 348-366.

Kousenidis, D. V, Ladas, A. C., \& Negakis, C. I. (2013). The effects of the European debt crisis on earnings quality. International Review of Financial Analysis, 30, 351-362.

Leuz, C., Nanda, D., \& Wysocki, P. D. (2003). Earnings management and investor protection: An international comparison. Journal of Financial Economics, 69, 505-527. https://doi.org/10.4324/9780203940136

McNichols, M. F. (2002). The quality of accruals and earnings: The role of accrual estimation errors. The Accounting Review, 77(SUPPL.), 61-69. https://doi.org/10.2308/accr.2002.77.s-1.35

Ohlson, J. A. (1995). Earnings, book values, and dividends in equity valuation. Contemporary Accounting Research, 11(2), 661-687.

Palma-Ruiz, J. M., Castillo-Apraiz, J., \& Gómez-Martl’inez, R. (2020). Socially responsible investing as a competitive strategy for trading companies in times of upheaval amid COVID-19: Evidence from Spain. International Journal of Financial Studies, 8(3), 41.

Persakis, A., \& Iatridis, G. E. (2015). Earnings quality under financial crisis: A global empirical investigation. Journal of Multinational Financial Management, 30, 1-35. https://doi.org/10.1016/j.mulfin.2014.12.002

Persakis, A., \& Iatridis, G. E. (2016). Audit quality, investor protection and earnings management during the financial crisis of 2008: An international perspective. Journal of International Financial Markets, Institutions and Money, 41, 73-101.

Persakis, A., \& Iatridis, G. E. (2017). The joint effect of investor protection, IFRS and earnings quality on cost of capital: An international study. Journal of International Financial Markets, Institutions and Money, 46, 129. https://doi.org/10.1016/j.intfin.2016.10.001

Porta, R. La, Lopez-De-Silanes, F., Shleifer, A., \& Vishny, R. W. (1998). Law and Finance. Journal of Political Economy, 106(6), 1113-1155. http://www.journals.uchicago.edu/t-and-c

Rababah, A., Al-Haddad, L., Sial, M. S., Chunmei, Z., \& Cherian, J. (2020). Analyzing the effects of COVID-19 pandemic on the financial performance of Chinese listed companies. Journal of Public Affairs, 20(4), e2440.

Schuchter, A., \& Levi, M. (2016). The fraud triangle revisited. Security Journal, 29(2), 107-121.

Shen, H., Fu, M., Pan, H., Yu, Z., \& Chen, Y. (2020). The impact of the COVID-19 pandemic on firm performance. Emerging Markets Finance and Trade, 56(10), 2213-2230.

Silva, A. F. da, Weffort, E. F. J., Flores, E. da S., \& Silva, G. P. da. (2014). Earnings management and economic crises in the Brazilian capital market. Revista de Administração de Empresas, 54, 268-283.

Wijayana, S., \& Gray, S. J. (2018). Institutional Factors and Earnings Management in the Asia - Pacific: Is IFRS Adoption Making a Difference? Management International Review, 59(2), 307-334. https://doi.org/10.1007/s11575-018-0371-1 